\title{
Effect of Salt Stress on Some Growth Indicators and Cellular Components of Wheat (Triticum aestivum L.) Callus
}

\author{
Helmee Hamed Khuder, Yusra Ismail Hussein AL-Taei \\ Department of Field Crops, College of Agriculture, AL-Qasim Green University, Babylon, Iraq \\ Email address: \\ yusra_ismai191@yahoo.com (Y. I. H. AL-Taei)
}

\section{To cite this article:}

Helmee Hamed Khuder, Yusra Ismail Hussein AL-Taei. Effect of Salt Stress on Some Growth Indicators and Cellular Components of Wheat (Triticum aestivum L.) Callus. International Journal of Applied Agricultural Sciences. Vol. 1, No. 4, 2015, pp. 91-94.

doi: 10.11648/j.ijaas.20150104.11

\begin{abstract}
The experiment was conducted to study the effect of sodium chloride $(\mathrm{NaCl})$ at the concentrations of $0.0,0.5,1.0$ and $1.5 \%$ on the callus cells. The Iraq wheat variety was grown in vitro for the purpose of knowing the effect of salt stress on some indicators and cellular components of callus by using a randomized complete design, at the laboratories of tissue culture propagation date palm unit in the College of Agriculture / University of Kufa during the period 2014-2015. Fresh and dry weight, the rate of absolute growth, percentage of dry matter of callus, content of the callus cells of proline, total soluble carbohydrates, sodium and potassium ions, effectiveness of the enzymes catalase and peroxidase study shock salt proteins in callus were determined as indicators of the effect of $\mathrm{NaCl}$ on the callus culture cells in the above salty medium and the results can be summarized, to control treatment achieved the highest average of (fresh callus weight, dry callus weight, the absolute growth rate of potassium ion), which was $(0.0805 \mathrm{~g}, 6.13 \mathrm{mg}, 3.147 \mathrm{mg} /$ day and $1.125 \%)$ respectively, while the conc. $1.5 \% \mathrm{NaCl}$ gave highest average in callus content of (proline, total soluble carbohydrates, sodium ion, the effectiveness of Catalase and Peroxidase enzyme and Salt shock proteins), which $(0.134 \mathrm{mg} / \mathrm{g}, 2.9527 \mathrm{mg} / \mathrm{g}, 0.1050 \%, 0.1510 \mathrm{Micromol} / \mathrm{protein} / \mathrm{min}$, $0.1127 \mathrm{Micromol} / \mathrm{protein} / \mathrm{min}$ and the emergence of small molecular weights), respectively.
\end{abstract}

Keywords: Salt Shock Proteins, Antioxidant Enzymes, Salt Stress, Triticum aestivum L.

\section{Introduction}

The bread wheat Triticum aestivum L. is the most important cereal crops cultivated in the world. It is the source of a major energy needed by the human because of its high nutritional value, (high rate of carbohydrates and proteins) [1]. It also highlights the salt stress danger of through toxic, osmosis and prejudice in the balance of nutrients as well as in physical and chemical characteristics because it increases the speed of the demolition of cell processes and thus stimulate the plant to form osmotic organizations such as proline, glycine betanin, and that the organization of molecules is controlled on these routes. These engines are proteins and metabolic intervention materials in ion balance [2], as well as the reduction in photosynthetic activity for salt and toxic effects (specific toxic effects) such as those resulting from hormonal imbalance and generate effective oxygen species [3] and [4], study the growth of callus in different types of wheat (T. aethiopicum Jakubz., T. macha Dek. Et. Men., T. polonicum L., T. compactum Host. and T. aestivum L.) under stress conditions ( 0 and $1.5 \%$ ) of $\mathrm{NaCl}$, the indicate that there were significant differences in fresh weight between concentrations and the mean was superior compared to other types T. macha Dek. et. Men. [5] studies the response callus induced from mature and immature embryos of three wheat varieties (Roshan, Niknezhad and Tabasi ) growth in the medium provider with $0,70,140,210$ and $280 \mathrm{mg} / \mathrm{L}$ of $\mathrm{NaCl}$, and found that the average callus growth had been reduced by increasing of salt concentration and in which was Roshan gave the highest callus growth from mature embryos. [6] studying mutations in vitro to improve the endurance by exposing callus Sakha 93 and Sohag3 cultivars in-vito from immature embryos to salt concentrations of $0,0.9$ and $1.2 \%$, and a found that the Sakha 93 var. was superior compared to other variety, which contained highest proline, salt concentration of $0.9 \%$ and exposed to 120 non-exhibition of gamma rays gave high proline content than the concentration of $1.2 \%$ which was exhibited to the same dose of gamma rays. In callus response (output of seeds) to salinity for several varieties of wheat (TJ83, Marav 2000 and Sindh81) under different concentrations of $\mathrm{NaCl}$ (75, 100 and $150 \mathrm{mM}$ ) [7] found that after 7 days of focusing salt, the carbohydrate content was high in Marav 2000 var. compared to other cultivars. [8] in their study to select tolerance 
varieties of wheat to salt stress in-vitro, in which they used six genotypes (Sebou, Anouar, Marzak, Ourgh, Tarek, Tomouh and Massa) and after induction callus resulting from immature embryos transfer to medium concentrations $(4,8.12$ and $16 \mathrm{~g} / \mathrm{l})$ of $\mathrm{NaCl}$, they found that $\mathrm{Na}$ concentration was increased while potassium behavior in different trend compared to sodium and Sebou genotype was superior significantly compared to rest genotypes in the endurance to salt stress. [9] study the effect of salt stress, which is concentrations of 50150 and $180 \mathrm{mM}$ of $\mathrm{NaCl}$ on protein pattern in wheat varieties (Sids1, Sakha69 and Gemmiza5) they found (in Sids1 var.) an appearance of molecular weights of 11,35 and $46 \mathrm{KD}$ in all concentrations of salt, but the treatment 50 and $150 \mathrm{mM}$ of $\mathrm{NaCl}$ showed molecular weights of 52 and 68 KD respectively while Sakha69 variety gave $27 \mathrm{KD}$ These weights not affected by salinity but formed three proteins weights molecular wihch is 11.52 and 68 $\mathrm{KD}$ resulted from the variety Gemmiza5 var. was found to be very sensitive to salt stress through the emergence of molecular weights 35-48 KD under all salt concentrations, but the protein molecular weight of $46 \mathrm{KD}$ were seen after treating this variety with $180 \mathrm{mM} \mathrm{NaCl}$. [10] found in their study on the effect of salt stress in the growth indicators, and antioxidant enzymes in three varieties of wheat (Tekirdag, Pehlivan and Flamura-85) in-vitro prone to salt stress at the concentrations of $(0-250 \mathrm{mM}$ $\mathrm{NaCl}$ ), there were an increase in the effectiveness of enzymes (Catalase and Peroxidase) resulted from exposure callus to salt stress conditions in which all varieties have followed the same behavior, but differed in their content of enzymes. Due to the importance of wheat crop, it had been chosen for this study by using different concentrations of salt because a lot of agricultural land in Iraq either saline or re-salinization which therefore targeted this experience to know the effect of salt stress in the cellular components of callus.

\section{Materials and Methods}

The Experiment was carried out at the propagation center of the date palm tissue culture, College of Agriculture, University of Kufa to study the effect of four concentrations of salt $(0.0,0.5$, 1.0 and $1.5 \% \mathrm{NaCl}$ ) on the callus cells of Iraq wheat variety. Mature embryos of wheat as cereals was washed by running water for several times to remove dust, then left in the water for several hours, and after that sterilized with alcohol ethyl $70 \%$ for 10 seconds, then placed in hypo chloride sodium (minor commercial) for 15 minutes then washed with sterile distilled water several times to remove traces of material sterilization and then the mature embryo separated embryos sterilized in petri dishes sterile This process was done inside Laminer air hood flow and then put in agriculture tube containing MS add $2.5 \mathrm{mg} / \mathrm{l}(2,4-\mathrm{D})$ to induce callus and then after 4 weeks transfer callus to anther tube contains the same medium with the concentrations of salt $(0.0,0.5,1.0$ and 1.5$) \%$ which left for five months this period with re-culture on the same medium and the same concentrations several times to maintain the callus and then the data were measured as follow:

1. Fresh weight of Callus (g).

2. The dry weight of Callus (mg).
3. Absolute growth rate ( $\mathrm{mg} /$ day).

4. The dry matter percentage (\%) was calculated according to the equation [11].

5. Proline ( $\mathrm{mg} / \mathrm{g}$ ) by the method of [12].

6. Total soluble sugars ( $\mathrm{mg} / \mathrm{g}$ ) was calculated according to [13].

7. Sodium and potassium $(\%)[14]$

8. Catalase (Micromol / $\mathrm{min} /$ protein) [15].

9. Peroxidase (Micromol / $\mathrm{min} /$ protein) [16].

10. Salt shock proteins (KD) [17].

Design and statistical analysis

Randomized complete design (CRD) was used and data were analyzed according to Genstat program and the means were compared according to $\left(\mathrm{LSD}_{0.05}\right)[18]$.

\section{Results and Discussion}

Data in table (1) indicate that salt concentrations caused a significant effects on callus growth rate. Fresh weight of callus was declined sharply with increasing concentrations of $\mathrm{NaCl}$ in medium Notes from Figure 1 show that the average and the highest rate of fresh weight obtain from control and $0.5 \%$ treatment $(0.0805$ and 0.0636$) \mathrm{g}$, respectively. While the was obtained at the concentration of $1.5 \%$ lowest rate $(0.0307 \mathrm{~g})$. The reason for this was that high concentrations of salt may lead to the inability of the cell to divide because of high osmotic pressure and the influence the ionian inside cells, as well as the lack in the ability of water and nutrients absorption due to decline in medium water potential.

As well as ion-induced toxicity by increasing concentrations of $\mathrm{Na}^{+}$within the plant tissue [19]. The dry weight of Callus was highest significantly at control and $0.5 \%$ treatments where the dry weight concentrations $(6.13$ and 5.50$) \mathrm{mg}$, respectively, which due to the increase in fresh weight.

Higher absolute growth rate of callus obtained of control and $0.5 \%$ concentrations $(3.147$ and 3.000$) \mathrm{mg} /$ day respectively and it was superior compared to other concentrations. The lowest rate obtained from $1.5 \%$ reached $(0.313 \mathrm{mg} /$ day $)$ It is due to that fresh and dry callus of Iraq wheat var. was optimum at these concentrations.

It appears that increasing salt proline increase in Callus varitiy wheat concentrations caused an increase in proline concentration which reached its high value at $1.5 \%(0.134 \mathrm{mg} /$ g) The lowest proline concentration obtained from control treatment $(0.029 \mathrm{mg} / \mathrm{g})$ This is due to the fact that proline acid increases with increasing concentrations of salinity, to amend the osmosis between the vacuum and the cell cytoplasm [20] as it begins to accumulate in the cytoplasm after the entry of $\mathrm{NaCl}$ and collect ions monovalent in the vacuums [21].

It linked also water from salty medium to reduce the toxicity of the salt ions at high salt concentrations in addition to its impacted on the protection of enzymes and cellular organelles [22], as well as its uses as storage for nitrogen, carbon and energy [23]. proline building materials in the cells (Glutamic and ornithine), used in conversion to proline acid by increasing enzyme activities involved in its construction [24] and increases the accumulation stimulate enzymes built. 
Table 1. Effect of salt stress on growth indicators of callus after 5 months of agriculture in the salt medium.

\begin{tabular}{lllll}
\hline Dry matter (\%) & Absolute growth rate (mg / day) & Callus dry weight (mg) & Fresh weight of callus (g) & Concentrations \% \\
\hline 7.43 & 3.147 & 6.13 & 0.0805 & 0.0 \\
6.20 & 3.000 & 5.50 & 0.0636 & 0.5 \\
5.97 & 1.813 & 3.57 & 0.0599 & 1.0 \\
5.5 & 0.313 & 3.00 & 0.0307 & 1.5 \\
3.989 & 1.909 & 2.387 & 0.0258 & L.S.D \\
\hline
\end{tabular}

Vizpyrroline carboxylic acid synthetase and Pyrroline carboxylic acid reductase and this process is controlled by genes called Osmotically regulated gene which act as rule on proline control of the production of proline and glycine Betaine production protect the cell from moisture loss [25]

Table 2. Effect of salt stress on physiological and biochemical components of callus after 5 months of agriculture in the medium salt.

\begin{tabular}{|c|c|c|c|c|c|c|}
\hline Proline(Mg/g) & Peroxidase (Mmol/min/p) & Catalase $(\mathrm{Mmol} / \mathrm{min} / \mathrm{p})$ & Potassium(\%) & Sodium (\%) & Total soluble sugars (Mg/g) & Conc. $\%$ \\
\hline 0.029 & 0.0673 & 0.0118 & 1.125 & 0.0131 & 2.9527 & 0.0 \\
\hline 0.059 & 0.0850 & 0.0381 & 0.638 & 0.0275 & 2.7122 & 0.5 \\
\hline 0.102 & 0.0970 & 0.1223 & 0.363 & 0.0750 & 2.4752 & 1.0 \\
\hline 0.134 & 0.1127 & 0.1510 & 0.200 & 0.1050 & 2.4320 & 1.5 \\
\hline 0.0096 & 0.02781 & 0.05337 & 0.0771 & 0.0209 & 0.4532 & L.S.D 0.05 \\
\hline
\end{tabular}

Table 2 indicates that carbohydrates $1.5 \%$ salt concentration significantly compared to other concentrations of salt The lowest rate of carbohydrates was $(2.4320 \mathrm{mg} / \mathrm{g})$ was obtains from control treatment. The reason for this increase is due to lowest ability of callus in the transformation of simple sugars to complex sugars. Therefore, these organic compounds will work an important role to adapt to withstand salinity, where it works with proline effort to raise osmatic [26]. Sodium was significantly higher at $1.5 \%$ salt concentration component $\mathrm{NaCl}$ concentrations increase in medium the center has been at the $(0.1050 \%)$, while the lowest rate $(0.0131 \%)$ was obtain from control treatment in opposite of potassium concentration as high as possible and focus when control and $(0.5 \%)$, where the focus was (1.125 and 0.638$) \%$, respectively, while the lowest concentration of potassium was at $(1.5 \%) \mathrm{NaCl}(0.200 \%)$. The concentrations of 1.0 and $1.5 \%$ gave higher effective of Catalase enzyme, and was the effectiveness of this enzyme at these concentrations were $(0.1223$ and 0.1570$)$ Micromol / min / protein respectively. Catalase increases in callus was due to increases in salt concentrations to increase resistance to the conditions of stress acting on the induction voltage oxidative of increasing formation roots effective oxygen (ROS) such as Superoxidase,

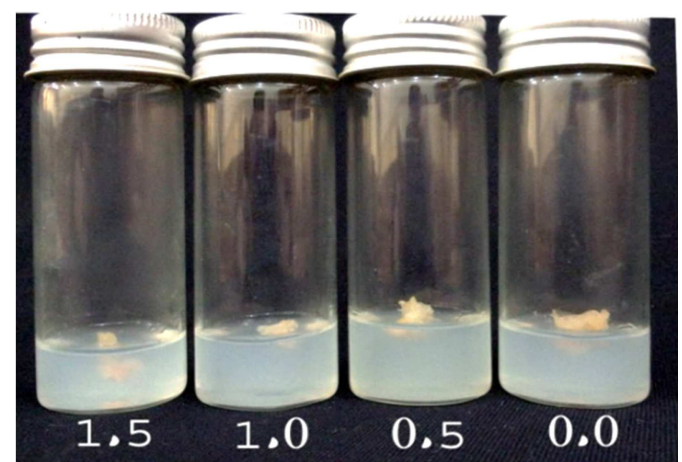

Fig. 1. Effect of salt stress on the growth of callus.

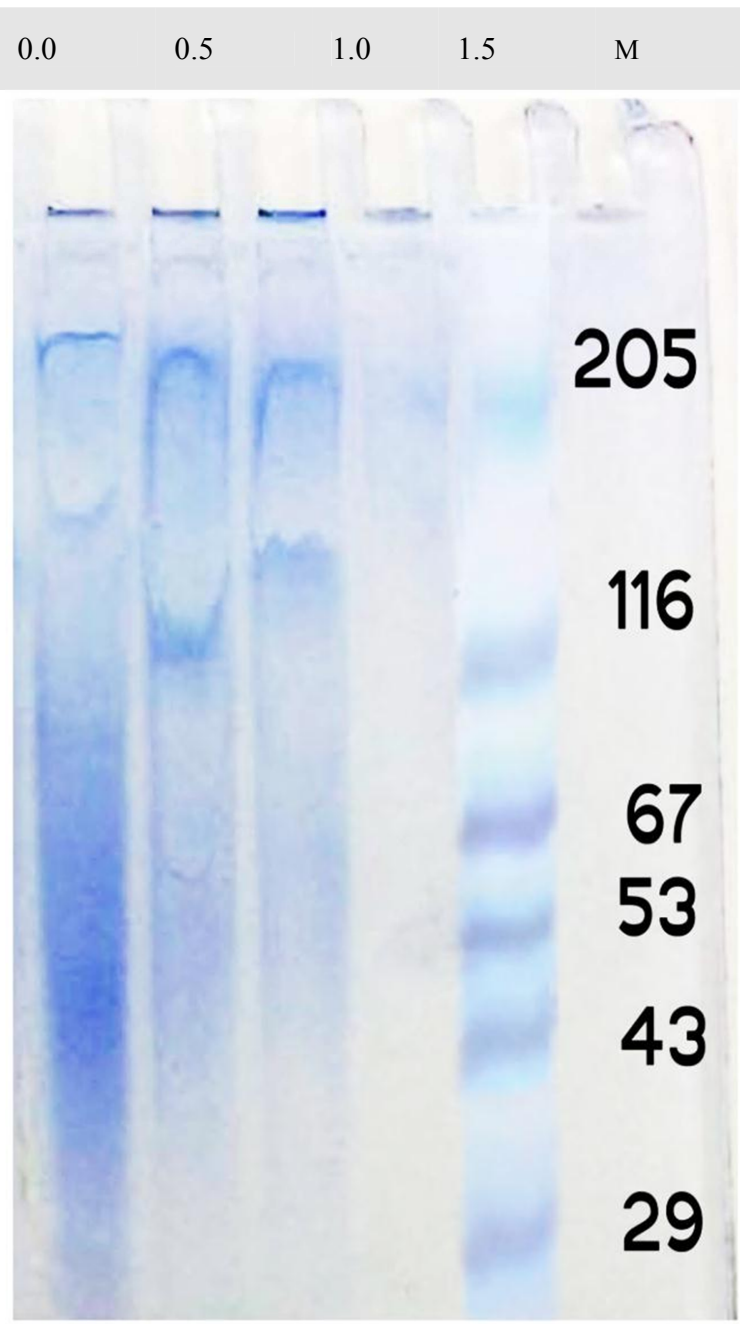

Fig. 2. SDS-PAGE profile of total proteins.

Hydrogen Peroxid and Hydroxyl radical harmful to plants and which caused when the cell displays it was increased Peroxidase get rid of ROS by liposuction hydrogen peroxide 
[27]. Peroxidase activity was increased at the concentrations of 1.0 and 1.5\% (0.0970 and 0.1127) Micromol / $\mathrm{min} /$ protein respectively. Figure 2 shows that in control treatment arise proteins with molecular weights of $(340,205,126$ and 91) KD while in salt concentration $0.5 \% \mathrm{NaCl}$ arise proteins molecular weights of $(340,205,116$ and 60$) \mathrm{KD}$, while at $1.0 \% \mathrm{NaCl}$ arise proteins molecular weights of $(340,205,120$ and 67) KD and the conc. of $1.5 \% \mathrm{NaCl}$ appeared weights $(340,205,126$ and 53) KD This shows that whenever the salt concentration increased show of small molecular weight proteins, these proteins play a role in cell protection.

\section{References}

[1] Braun, H. J.; G. Atlin and T. Payne. 2010. Multilocation testing as a tool to identify plant response to global climate change. In reynolds crp (Ed.). Climate change and crop production, CABI London UK.

[2] Ashraf, M. and M. R. Foolad. 2007. Roles of glycine betaine and proline in improving plant biotic stress resistance. Environ. Exp. Bot., 59:206-216.

[3] Munns, R.2005.Genes and salt tolerance: bringing them together. New Phytol., 167:645-663.

[4] Terletskaya, N. and K. Nina.2010. Tissue culture in vitro as a model system for studying the effects of abiotic stresses on different species of wheat. Advances in Environmental Technology and Biotechnology, 1:102-107.

[5] Fazeli-nasab, B.; O. Masour and A. Mehdi. 2012. Estimate of callus induction and volume immature and mature embryo culture and respons to in-vitro salt resistance in presence of $\mathrm{NaCL}$ and $\mathrm{ABA}$ in salt tolerant wheat cultivars. Intl Agri Crop Sci., 4(1):8-16.

[6] El-Sayed, O. E.; 1A. A. Rizkalla and S. R. S. Sabri. 2007. In vitro mutagenesis for genetic improvement of salinity tolerance in wheat. Res. J. Agri. Bio. Sci., 4(5): 377-383.

[7] Choudhary, M. R.; U. D. Muhammad.; M. S. Ghulam.; M. Erum and A. K. Salman.2009. Germination, growth and callus responses in EMS treated local cultivars of wheat (Triticum aestivum L.) under in vitro salt stress. J. Iran. Chem. Soc., 6:230-237.

[8] Koutoua, A.; D. Hmouni; H. Elyacoubi ; R. Moutiq ; L. Zidane and A. Rochdi. 2015. Functional variation of potassium, sodium and chloride ions in selected salt- tolerant- calli from durum wheat (Triticum durum Desf.) mature embryo. J. Mater. Environ. Sci., 6 (5): 1285-1291.

[9] Barakat, H.2003.Interactive effect of salinity and certain vitamins on gene expression and cell division. Int. J. Agri. Bio., 5(3):219-225.

[10] Sen, A. and S. Alikamanoglu. 2011. Effect of salt stress on growth parameters and antioxidant enzymes of different wheat (Triticum aestivum $\mathrm{L}$.) varieties on in vitro tissue culture. Fress. Environ. Bull., 20: 489-495.

[11] Sakthivelu, G.; M. K. Akitha Devi; P. Giridhar; T. Rajasekaran; G. A. Ravishankar; T. Nedev and G. Kosturkova. 2008. Drought-induced alterations in growth, osmotic potential and in vitro regeneration of soybean cultivars. Gen. Appl. Plant Physiol., (Special Issue) 34 (1-2): 103-112.
[12] Bates, L. S.; R. P. Waldren and I. D. Teare. 1973. Rapid determination of free proline for water stress studies. Plant Soil, 39:205-207.

[13] Herbert, D.; P. J. Phillips and R. E. Strange. 1971. Determination of total carbohydrate. In: Norris, J. R. and Robbins, D. W. (eds.) Methods in Microbiology. chapter 3. pp. 209- 344. Academic Press, New York.

[14] Sahaf, F. H.1989. Applied plant nutrition. Baghdad University. The Ministry of Higher Education and Scientific Research. Higher Education Press in Mosul. Iraq. p260.

[15] Aebi, H. 1984. Catalase in vitro, Method of Enzymology. Plant Cell Physiol, 105:121-126.

[16] Nezih, M. 1985. The peroxidase enzyme activity of some vegetables and its resistance to heat. Food Agric., 36:877-880.

[17] John, M. W. 2002.The protein protocols handbook. University of Hertfordshire, Hatfield, UK. Pp.61-67.

[18] Alsahoeke, M. and K. M. Wahib. 1990. Applications in the design and analysis of experiments. The Ministry of Higher Education and Scientific Research. Baghdad University. Iraq. p.488.

[19] Sairam, R. K. and A. Tyagi. 2004. Physiology and molecular biology of salinity stress tolerance in plants. Curr. Sci,. 86(3): 407-417.

[20] Kavi Kishore, P. B. ; S. Sangam ; R. N. Amrutha ; P. S. Laxmi; K. R. Naidu ; K. R. Rao ; S. Rao ; K. J. Reddy ; P. Theriappan and N. Sreenivasulu. 2005. Regulation of proline biosynthesis, degradation, uptake and transport in higher plants: its implications in plant growth and abiotic stress tolerance. Curr. Sci., $88,424-438$.

[21] Parida, S. K. and A.B. Das.2005. Salt tolerance and salinity effects on plants. Ecotoxicol. Environ. Safety.60:324-349.

[22] Munns, R. and M. Tester. 2008. Mechanisms of salinity tolerance. Annual Review of Plant Biology, 59:651-681.

[23] Kumar, S.; A. M. Reddy and C. Sudhakar. 2003. NaCl effects on proline metabolism in two high yielding genotypes of mulberry (Morus alba L.) with contrasting salt tolerance. Plant Sci., 165: 1245-1251.

[24] Ashraf, M. and A. Orooj. 2006. Salt stress effects on growth, ion accumulation and seed oil concentration in an arid zone traditional medicinal plant ajwain (Trachyspermum ammi [L.] Sprague). J. Arid Environ., 64 : 209-220.

[25] Hanafy-Ahmed, A. H.; H. M. Hassan; M. M. A. Gad and M. A. Amin. 2002. Micropropagation of Myrtus communis and increasing its tolerance to salinity stress by using polyamines. Proceedings of the $2^{\text {nd }}$ Congress on Recent Technologies in Agriculture, Faculty of Agriculture, Cairo University $28-30$ October. Pp.995- 1011.

[26] Greenway, H. and R. Munns. 1980. Mechanisms of salt tolerance in non halophytes. Ann. Rev. Plant Physiol., 31: 149-190.

[27] Gara, L. D.; M. C. Pinto and F. Tommasi. 2003. The antioxidant systems vis-a-vis reactive oxygen species during plant-pathogen interaction. Plant Physiol. and Biochem., 41:863-870 